\title{
EFFECT OF HIGH HYDROSTATIC PRESSURE (HHP) PROCESSING ON ORGANOLEPTIC PROPERTIES AND SHELF LIFE OF FISH SALAD WITH MAYONNAISE
}

\author{
B. Salamon ${ }^{a *}$, A. Tóth ${ }^{\mathrm{a}}$, P. Palotás ${ }^{\mathrm{a}}$, G. Südi ${ }^{\mathrm{b}}$, B. Csehi ${ }^{\mathrm{a}}$, Cs. Németh ${ }^{\mathrm{c}}$ and L. Friedrich ${ }^{\mathrm{a}}$ \\ ${ }^{a}$ Department of Refrigeration and Livestock Products Technology, Faculty of Food Science, Szent István \\ University, H-1118 Budapest, Ménesi út 43-45. Hungary \\ ${ }^{\text {b} P L P ~ S e a f o o d ~ H u n g a r y ~ L t d ., ~ H-2040 ~ B u d a o ̈ r s, ~ T o ̈ r o ̈ k b a ́ l i n t i ~ u ́ t ~ 23 . ~ H u n g a r y ~}$ \\ ${ }^{\mathrm{c} C}$ apriovus Ltd., H-2317 Szigetcsép, Dunasor 073/72. Hungary
}

(Received: 18 March 2016; accepted: 14 July 2016)

\begin{abstract}
The aim of the present study was to evaluate the effect of high hydrostatic pressure (HHP) processing (at 450 or 600 MPa for $300 \mathrm{~s}$ ) on microbial quality as well as on organoleptic properties of fish salad with mayonnaise during 26 days of storage at 5 and $10{ }^{\circ} \mathrm{C}$. The salad contained diced smoked trout fish, mayonnaise, and different kinds of spices. These freshly made salads usually have only a couple of days of shelf life. The HHP treatment basically did not affect the physical and organoleptic characteristics of the fish salad with mayonnaise. At both storage temperatures, the HHP treated samples showed enhanced safety and increased shelf-life up to 3 weeks.
\end{abstract}

Keywords: high pressure processing (HHP), fish salad, sensory characteristics, shelf-life

High hydrostatic pressure (HHP) processing is a non-thermal technology used to enhance safety of food products and maintain their quality (CONSIDINE et al., 2008; RENDUELES et al., 2011). It is also effective in preserving the organoleptic attributes of many foods. In the present study we researched how we could enhance the shelf life of fish salad with mayonnaise and meanwhile basically avoid its quality changes. It can serve as a ready meal product or dressing for other vegetable salads. Fish products in general have high nutritional value, but they are also perishable and represent a high microbiological risk for the consumer (NOvOTNY et al., 2004), especially in less processed products like mild smoked fish. The chances of outbreaks are even greater when high risk ingredients, such as raw egg, are used to prepare a specific meal or food product (HowARD et al., 2012). Being aware of the high risk of crosscontaminations is elementary. Basically, these freshly prepared salads, if vacuum packaging and cold storage is applied, have a shelf life only up to $3-5$ days.

Application of HHP processing might provide a solution for preservation of fish salad with mayonnaise. A few minutes of HHP treatment at $300 \mathrm{MPa}$ or higher level significantly reduces the initial load and/or growth rate of spoilage-causing microorganisms and enzymatic activity in many fish products stored under chilled conditions (ERKAN et al., 2010; KAMALAKANTH et al., 2011). Spoilage microbiota in mild smoked rainbow trout fillets was low (around 1-2 $\log \mathrm{CFU} \mathrm{g}{ }^{-1}$ ) throughout 41 days of storage due to 400 or $600 \mathrm{MPa} 5 \mathrm{~min}$ HHP processing (MengDen et al., 2015). Several studies have shown the presence and growth potential of L. monocytogenes in mayonnaise-based salads, with the highest prevalence of this pathogen being observed in products containing processed seafood (GomBAs et al., 2003;

\footnotetext{
* To whom correspondence should be addressed. Phone: 0036202959186; e-mail: Salamon.Bertold@etk.szie.hu
} 
Coillie et al., 2004; UytTendaele et al., 2009; Di Pinto et al., 2010). HHP has been demonstrated to be capable of inactivating L. monocytogenes or E. coli in seafood (LAKShManan \& DalgaArd, 2004; Ramaswamy et al., 2008), other Listeria strains (Ferreira et al., 2016), and Salmonella enteritidis in egg products (IsIKER et al., 2003). At the same time, it maintains sensory properties in various kinds of food products (ANDRÁssY et al., 2006; FARKAS et al., 2014). The objectives of this study were to examine the maintenance of quality attributes of fish salad with mayonnaise during enhancing their shelf life by high hydrostatic pressure treatment.

\section{Materials and methods}

\subsection{Sample preparation}

The raw materials were provided and the sample preparation was carried out in the plant of PLP Seafood Hungary Ltd. in Budaörs. Ingredients of the fish salad were: home-made mayonnaise (sunflower oil, Dijon mustard, egg yolk, lemon juice, salt, and cayenne pepper), smoked trout meat, and mixture of spices assured by the PLP Seafood Hungary Ltd. During the preparation of the samples smoked trout flesh was torn/diced into small pieces and mixed with mayonnaise and spices. Then the fish salad was portioned to $100 \mathrm{~g}$ samples, vacuum packed into foil pouches, and delivered to the university. During the $1 \mathrm{~h}$ transport cold storage at $2{ }^{\circ} \mathrm{C}$ was assured. Samples were subsequently in less than one h HHP processed.

\subsection{High hydrostatic pressure treatments and storage}

The pressure treatments were performed in a Resato 100-2000 FPU high-pressure equipment at the Szent István University. The samples were pressure-treated at 450 and $600 \mathrm{MPa}$ for 5 $\min$ at $14-17^{\circ} \mathrm{C}$. The pressure transmitting medium was PG fluid, provided by the producer. The pressure was increased by $100 \mathrm{MPa} / \mathrm{min}$ and released within less than 5 seconds. The temperature increase due to adiabatic heating was approximately $2.5^{\circ} \mathrm{C}$ per $100 \mathrm{MPa}$. After pressure treatments, all samples, including untreated control samples, were randomly divided into two groups and stored at 5 or $10^{\circ} \mathrm{C}$ for up to 26 days. From each experimental treatment 2 pouches of samples were analysed on the 0 th, 7 th, 14 th, 21 st, and 26th days of storage.

\subsection{Colour and $\mathrm{pH}$ measurements}

Colour values such as $L^{*}$ (lightness), $a^{*}\left(+a\right.$, red; $-a$, green), and $b^{*}$ (+b, yellow; $-b$, blue) were measured at 5 different points along the pouches using a Konica Minolta CR-400 colorimeter. The overall differences in $\mathrm{L}^{*}, \mathrm{a}^{*}$, and $\mathrm{b}^{*}$ values in case of each HHP treatment in comparison to untreated samples were evaluated, using $\Delta \mathrm{E}$ according to Eq. (1).

$$
\Delta E_{b}^{*}=\sqrt{\left(\Delta L^{*}\right)^{2}+\left(\Delta a^{*}\right)^{2}+\left(\Delta b^{*}\right)^{2}}
$$

The $\mathrm{pH}$ of samples was determined in triplicate by immersing a $\mathrm{pH}$ electrode (Testo 209) into the fish salad. 


\subsection{Microbiological examinations}

Samples were analysed for numbers of aerobic mesophilic microorganisms after high pressure treatments and also during storage. Ten grams of each sample were obtained aseptically, Stomachered for $2 \mathrm{~min}$ with $90 \mathrm{ml}$ of diluent, and 10-fold serial dilutions were made. The appropriate dilutions were plated on Nutrient count agar. Plates were incubated for $48 \mathrm{~h}$ at $37^{\circ} \mathrm{C}$, and the colonies were counted by a colony counter. Microbial data were transformed into logarithms of the number of colony-forming units $\left(\log \mathrm{CFU} \mathrm{g}^{-1}\right)$.

\subsection{Sensory evaluation}

Sensory analysis was performed by a 10-member panel. The panel consisted of 10 researchers and technicians of Szent István University (50\% male/female, aged between 25 and 57 years). The panel regularly performs sensory analysis and has some experience with evaluation of fish products. All samples were given a three digit number, adjusted to room temperature before sensory analysis, and served randomly. The evaluated attributes were intensity of colour, aroma, and taste, beside the textural parameters (hardness of fish, viscosity of mayonnaise) and mosaicity (appearance of mosaic patterns of diced fish in the salad). They always had to compare the HHP treated samples to the control sample on an 11-point scale, where $(-5)$ corresponded to "dislike very much", $(+5)$ corresponded to "like very much", and (0) to "there is not any difference".

\subsection{Statistical analysis}

The experiments were run in triplicate and the data were presented as mean with standard deviation. Statistical analysis was performed using SPSS (Version 19.0, SPSS Inc, Chicago, $\mathrm{IL}$ ). The results were analysed using one-way analysis of variance (ANOVA), the level of significance was established at $\mathrm{P}<0.05$.

\section{Results and discussion}

\subsection{Changes of the $\mathrm{pH}$ value}

Evolution of $\mathrm{pH}$ is presented in Table 1. Initial $\mathrm{pH}$ of the fish salads were in the range of 5.6-5.7. After 7 days, the $\mathrm{pH}$ of control samples began a continuous, significant decrease, until approximately a $\mathrm{pH}$ of 5.3 , at which point it seemed to stabilize. In contrast, the $\mathrm{pH}$ values of 450 and $600 \mathrm{MPa}$ pressure-treated samples stored at $5{ }^{\circ} \mathrm{C}$ fluctuated in the same range (5.6-5.8) throughout the entire storage. Larger, but similar fluctuations and changes occurred in case of the treated samples stored at $10{ }^{\circ} \mathrm{C}$. Decrease in the $\mathrm{pH}$ value of the control samples are likely caused by bacterial growth, as these samples parallel with the decreasing $\mathrm{pH}$ also showed deterioration and unpleasant sensory attributes. The $\mathrm{pH}$ of pressurized samples remained constant during storage, and sensory results were appropriate as well as microbial quality. Therefore, in case of mayonnaise-based fish salads, the decrease in $\mathrm{pH}$ can be an indicator for microbial spoilage. 
Table 1. Changes of the $\mathrm{pH}$ values during chilled storage

\begin{tabular}{|c|c|c|c|c|c|c|}
\hline \multirow{2}{*}{$\begin{array}{l}\text { Days of } \\
\text { storage }\end{array}$} & \multicolumn{2}{|c|}{ Control } & \multicolumn{2}{|c|}{$450 \mathrm{MPa}$} & \multicolumn{2}{|c|}{$600 \mathrm{MPa}$} \\
\hline & $5^{\circ} \mathrm{C}$ & $10^{\circ} \mathrm{C}$ & $5^{\circ} \mathrm{C}$ & $10{ }^{\circ} \mathrm{C}$ & $5^{\circ} \mathrm{C}$ & $10{ }^{\circ} \mathrm{C}$ \\
\hline 0 & $5.71 \pm 0.02^{\mathrm{Aa}}$ & $5.62 \pm 0.02^{\mathrm{Aa}}$ & $5.65 \pm 0.02^{\mathrm{Aa}}$ & $5.59 \pm 0.03^{\mathrm{Ba}}$ & $5.78 \pm 0.02^{\mathrm{Aa}}$ & $5.88 \pm 0.04^{\mathrm{Aa}}$ \\
\hline 7 & $5.83 \pm 0.03^{\mathrm{Aa}}$ & $5.68 \pm 0.06^{\mathrm{Aa}}$ & $5.84 \pm 0.03^{\mathrm{Aa}}$ & $5.90 \pm 0.03^{\mathrm{Cb}}$ & $5.69 \pm 0.06^{\mathrm{Aa}}$ & $5.69 \pm 0.06^{\mathrm{Aa}}$ \\
\hline 14 & $5.61 \pm 0.03^{\mathrm{Ba}}$ & $5.13 \pm 0.03^{\mathrm{Cc}}$ & $5.82 \pm 0.03^{\mathrm{Aa}}$ & $5.55 \pm 0.06^{\mathrm{Bb}}$ & $5.79 \pm 0.02^{\mathrm{Aa}}$ & $5.98 \pm 0.04^{\mathrm{Cc}}$ \\
\hline 21 & $5.32 \pm 0.05^{\mathrm{Cb}}$ & $5.08 \pm 0.06^{\mathrm{Cc}}$ & $5.72 \pm 0.02^{\mathrm{Aa}}$ & $5.73 \pm 0.09^{\mathrm{Aa}}$ & $5.76 \pm 0.04^{\mathrm{Aa}}$ & $5.77 \pm 0.06^{\mathrm{Aa}}$ \\
\hline 26 & $5.29 \pm 0.03^{\mathrm{Cb}}$ & $5.2 \pm 0.03^{\mathrm{Cb}}$ & $5.75 \pm 0.02^{\mathrm{Aa}}$ & $5.64 \pm 0.03^{\mathrm{Aa}}$ & $5.83 \pm 0.13^{\mathrm{Aa}}$ & $5.92 \pm 0.03^{\mathrm{Cb}}$ \\
\hline
\end{tabular}

Values are given as mean \pm standard deviation $(n=3)$

Means indicated by different capital letters in the same column differ significantly $(\mathrm{P}<0.05)$

Means indicated by different lowercase letters in the same row differ significantly $(\mathrm{P}<0.05)$

\subsection{Colour changes}

After 450 and $600 \mathrm{MPa}$ HHP treatments, no changes could be observed in the colour of the fish salads with mayonnaise. All the colour values $\left(\mathrm{L}^{*}, \mathrm{a}^{*}\right.$, and $\left.\mathrm{b}^{*}\right)$ remained very close to the initial control results. During the 26-day refrigerated storage at 5 or $10{ }^{\circ} \mathrm{C}$, the colour values fluctuated in each case within a relatively narrow range close to the initial values, no systematic colour changes were detectable between the control and the 450 and $600 \mathrm{MPa}$ pressure-treated samples (Fig. 1). Consequently, no noticeable colour changes have occurred as an effect of pressure treatment in either colour parameters.

The $\Delta \mathrm{E}^{*}$ ab total colour difference value, which includes all results of $\mathrm{L}^{*}, \mathrm{a}^{*}$, and $\mathrm{b}^{*}$ and makes distinct categories for the human eye, showed that HHP treatment caused only slight differences in the colour of the fish salad samples. Even during the $10{ }^{\circ} \mathrm{C}$ storage, the $\Delta \mathrm{E}^{*}{ }_{\mathrm{ab}}$ scores of pressure treated samples remained at low level, colour changes due to the pressure treatment appeared to be mainly in the noticeable category or below.
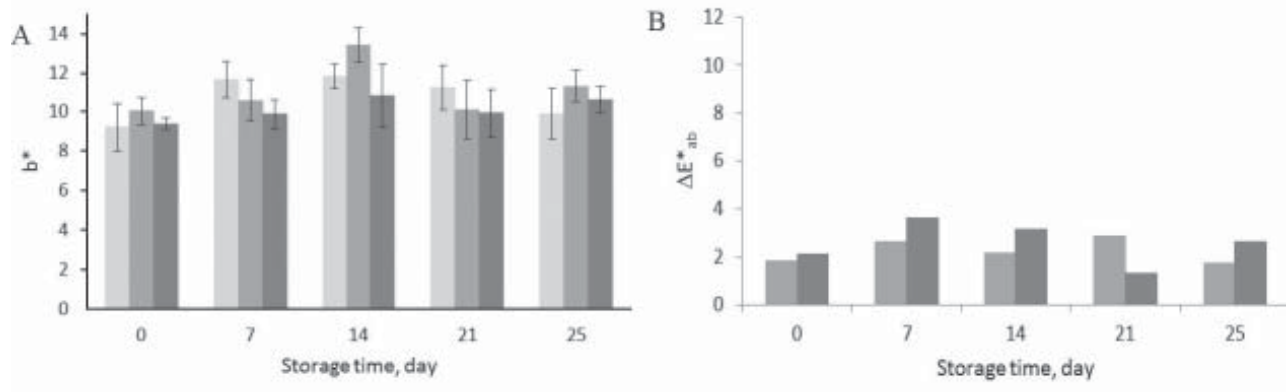

Fig. 1. Changes of colour properties (A) and $\Delta \mathrm{E}^{*}{ }_{\mathrm{ab}}$ values (B) during $10{ }^{\circ} \mathrm{C}$ storage due to high pressure treatment : Control; : $450 \mathrm{MPa}$; : $600 \mathrm{MPa}$

\subsection{Microbiological results}

Mean initial populations of mesophilic bacteria in unpressurized (control) fish salad with mayonnaise samples was $4.26 \log \mathrm{CFU} \mathrm{g}{ }^{-1}$. Microbiological investigations showed that the 
pressure treatment of 450 and $600 \mathrm{MPa}$ resulted 1.06 and $1.94 \log$ reductions in the initial bacteria count, respectively. It is thought that this inactivation is due to its direct effect on the morphology, biochemical reactions, genetic mechanism, cell membranes, and the wall of microorganisms (Hoover et al., 1989). HHP primarily affects functions of the cell membrane through inactivation of membrane-bound proteins and pressure-induced phase transitions of the lipid bilayer (HARTMANN et al., 2006). HHP processing can induce efficiently the elimination of L. monocytogenes and E. coli in smoked fish fillets (MENGDEN et al., 2015). However, our mayonnaise-based fish salad samples likely contained Salmonella spp. due to raw egg yolk and spores of Bacillus spp. and Clostridium perfringens due to different spice ingredients, which can explain the relatively modest effect of HHP processing at $600 \mathrm{MPa}$.

Figure 2 shows the growth of aerobic mesophilic microorganisms in untreated and HHP-treated samples stored at 5 or $10^{\circ} \mathrm{C}$ for 26 days. Mesophilic counts in control samples stored at $10{ }^{\circ} \mathrm{C}$ approached $7.0 \log \mathrm{CFU} \mathrm{g}{ }^{-1}$ around the eighth day of storage, which is considered as the upper acceptable limit for fresh water and marine species by ICMSF (2002). These samples had already sour odour and showed deterioration during sensory tests. Untreated samples stored at $5{ }^{\circ} \mathrm{C}$ did not exceed this limit even till the end of the storage.

As it can be seen, in all types of samples, number of mesophilic bacteria increased gradually during storage either at 5 or $10{ }^{\circ} \mathrm{C}$. HHP treated samples (450 and $600 \mathrm{MPa}$ ) stored at $5{ }^{\circ} \mathrm{C}$ showed approximately $1.0 \log$ cycle lower level in bacteria counts during the entire storage compared to control results, and reached the counts $<5.0 \log \mathrm{CFU} \mathrm{g}{ }^{-1}$ at the end of storage period. During the $10{ }^{\circ} \mathrm{C}$ refrigerated storage, $450 \mathrm{MPa}$ treated samples showed around $2.0 \log$ cycle lower level in the microbial load in comparison to control samples, and $600 \mathrm{MPa}$ treated samples had even greater difference, nearly $3.0 \log$ cycle. In both cases, the results did not reach the counts $7.0 \log \mathrm{CFU} \mathrm{g}{ }^{-1}$ till the end of storage.

Microbial shelf-life can be enhanced by HHP treatments (450 and $600 \mathrm{MPa}$ ) from approximately 1 week up to 3 weeks in case of $10{ }^{\circ} \mathrm{C}$ refrigerated storage. During $5{ }^{\circ} \mathrm{C}$ storage, the safety of the fish salads is more improved and even longer shelf-life is achievable.
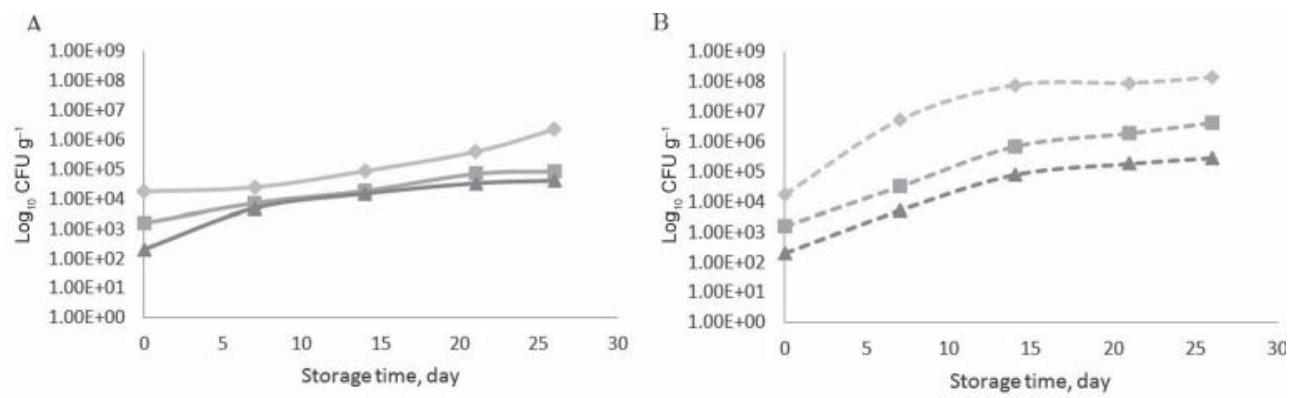

Fig. 2. Changes in total plate count during $5^{\circ} \mathrm{C}(\mathrm{A})$ and $10{ }^{\circ} \mathrm{C}(\mathrm{B})$ storage

— C Control $5{ }^{\circ} \mathrm{C} ;-\div$ - $450 \mathrm{MPa} 5{ }^{\circ} \mathrm{C}$; — $600 \mathrm{MPa} 5{ }^{\circ} \mathrm{C}$;

-: Control $10^{\circ} \mathrm{C} ;-\square-: 450 \mathrm{MPa} 10^{\circ} \mathrm{C} ;-{ }^{-1}-: 600 \mathrm{MPa} 10^{\circ} \mathrm{C}$

\subsection{Sensory analysis}

The testing was done only for 21 days, considering the microbiological spoilage. The 0 day results show that pressure treatment basically did not change any of the sensory attributes. 
The panellists detected merely a slight difference between treated samples and controls, which resulted in average (-1.2) in the aroma attribute of $450 \mathrm{MPa}$ treated sample. Also, based upon the results of the last day testing, there were no larger deviations in the essential properties between the pressure-treated and control samples during storage (Fig. 3). The panellists in general might prefer the pressure treated samples stored at $10^{\circ} \mathrm{C}$ more.

Since sensory appearance plays an important role in the purchase decisions of costumers (GARBER et al., 2003), it is likely that the pressurised mayonnaise-based fish salads can be as well accepted as the original product.

A

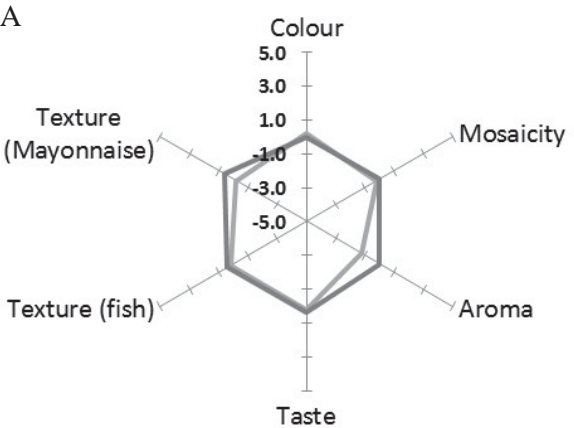

B

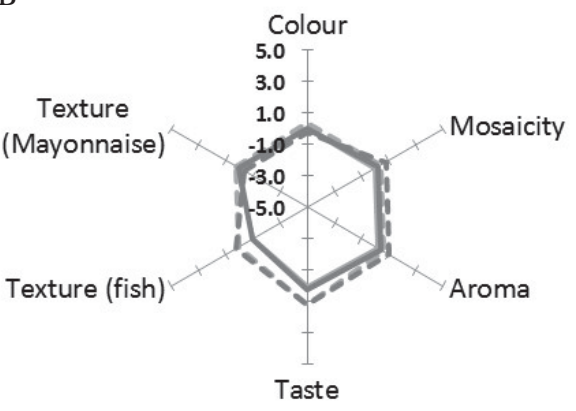

Fig. 3. Results of sensory analysis for pressure treated samples on 0 . day (A) and 21. day of storage (B). ——: $450 \mathrm{MPa} 5{ }^{\circ} \mathrm{C}$; ——: $600 \mathrm{MPa} 5{ }^{\circ} \mathrm{C} ;-\square-: 450 \mathrm{MPa} 10^{\circ} \mathrm{C}$; - - ${ }^{--:} 600 \mathrm{MPa} 10^{\circ} \mathrm{C}$

\section{Conclusions}

High hydrostatic pressure treatment combined with refrigerated storage is sufficient to enhance the shelf life of mayonnaise-based fish salad, and at the same time it is able to preserve its physical and organoleptic characteristics. Based on the sensory and microbiological results, the control samples were acceptable only up to 1 week compared to 3 weeks of HHP treated $\left(450\right.$ and $600 \mathrm{MPa}$ ) samples at $10^{\circ} \mathrm{C}$ storage, extending the shelf-life by 2 weeks. The shelf life and product safety can be more enhanced by ensuring $5{ }^{\circ} \mathrm{C}$ storage for the samples. The physical and organoleptic properties of the samples treated by high hydrostatic pressure remained similar to the initial quality along the entire storage. These results indicate that HHP can be used by the food industry as an additional post-packaging safety step in the production of multicomponent ready meals.

\section{References}

Andrássy, É., Farkas, J., Seregély, Zs., Dalmadi, I., Tuboly, E. \& Lebovics, V. (2006): Changes of hen eggs and their components caused by non-thermal pasteurizing treatments II. Some non-microbiological effects of gamma irradiation or hydrostatic pressure processing on liquid egg white and egg yolk. Acta Alimentaria, 35, $305-318$.

Coillie, E.V., Werbrouck, H., Heyndrickx, M., Herman, L. \& Rijpens, N. (2004): Prevalence and typing of Listeria monocytogenes in ready-to-eat food products on the Belgian market. J. Food Protect., 67, 2480-2487. 
Considine, K.M., Kelly, A.L., Fitzgerald, G.F., Hill, C. \& Sleator, R.D. (2008): High-pressure processing effects on microbial food safety and food quality. FEMS Microbiol. Lett., 281, 1-9.

Di Pinto, A., Novello, L., Montemurro, F., Bonerba, E. \& Tantillo, G. (2010): Occurrence of Listeria monocytogenes in ready-to-eat foods from supermarkets in Southern Italy. New Microbiol., 33, 249-252.

Erkan, N., Üretener, G. \& Alpas, H. (2010): Effect of high pressure (HP) on the quality and shelf life of red mullet (Mullus surmelutus). Innov. Food Sci. Emerg., 11(2), 259-264.

Farkas, V., Dalmadi, I. \& Balla, Cs. (2014): Effect of high hydrostatic pressure treatments on volatiles of berry purées. Acta Alimentaria, 43(Suppl.), 51-57.

Ferreira, M., Pereira, S., Almeida, A., Queirós, R., Delgadillo, I., Saraiva, J. \& Cunha, A. (2016): Effect of temperature and compression/decompression rates on high pressure inactivation of Listeria. Acta Alimentaria, $45,61-68$.

Garber, L.L., JR., HyatT, E.M. \& StarR, R.G., JR. (2003): Measuring consumer response to food products. Food Qual. Prefer., 14(1), 3-15.

Gombas, D.E., Chen, Y.H., Clavero, R.S. \& Scott, V.N. (2003): Survey of Listeria monocytogenes in ready-to-eat foods. J. Food Protect., 66, 559-569.

Hartmann, C., Mathmann, K. \& Delgado, A. (2006): Mechanical stresses in cellular structures under high hydrostatic pressure. Innov. Food Sci. Emerg., 7, 1-12.

Hoover, D.G., Metrick, C., Papineau, A.M., Farkas, D.F. \& Knorr, D. (1989): Biological effects of high hydrostatic pressure on food microorganisms. Food Technol., 43(3), 99-107.

Howard, Z.R., O'Bryan, C.A., Crandall, P.G. \& Ricke S.C. (2012): Salmonella in foods: evolution, strategies and challenges Salmonella enteritidis in shell eggs: Current issues and prospects for control. Food Res. Int., 45, $755-764$.

International COMmission On Microbiological SPeCIFications For Foods (ICMSF) (2002): Microorganisms in foods 7, Microbiological testing in food safety management. Kluwer Academic/Plenum Publishers, New York, USA. 362 pages.

IsiKer, G., GuRAKan, G.C. \& Bayindirli, A. (2003): Combined effect of high hydrostatic pressure treatment and hydrogen peroxide on Salmonella enteritidis in liquid whole egg. Eur. Food Res. Technol., 217, 244-248.

Kamalakanth, C.K., Ginson, J., Bindu, J., Venkateswarlu, R., Das, S., Chauhan, O.P. \& Gopal, T.K.S. (2011): Effect of high pressure on K-value, microbial and sensory characteristics of yellowfin tuna (Thunnus albacares) chunks in EVOH films during chill storage. Innov. Food Sci. Emerg., 12, 451-455.

LaKSHMANAN, R. \& DalgaARD, P. (2004): Effects of high-pressure processing on Listeria monocytogenes, spoilage microflora and multiple compound quality indices in chilled cold-smoked salmon. J. Appl. Microbiol., 96, 398-408.

Mengden, R., RöHner, A., Sudhaus, N. \& KLein, G. (2015): High-pressure processing of mild smoked rainbow trout fillets (Oncorhynchus mykiss) and fresh European catfish fillets (Silurus glanis). Innov. Food Sci. Emerg., 32, $9-15$.

Novotny, L., Dvorska, L., Lorencova, A., Beran, V. \& Pavlik, I. (2004): Fish: a potential source of bacterial pathogens for human beings. Vet. Med.-Czech, 49(9), 343-358.

Ramaswamy, H.S., Zaman, S.U. \& Smith, J.P. (2008): High pressure destruction kinetics of Escherichia coli (O157:H7) and Listeria monocytogenes (Scott A) in a fish slurry. J. Food Eng., 87, 99-106.

Rendueles, E., Omer, M.K., Alvseike, O., Alonso-Calleja, R., Captta, R. \& Prieto, M. (2011): Microbiological food safety assessment of high hydrostatic pressure processing. LWT - Food Sci. Technol., 44, 1251-1260.

Uyttendaele, M., Busschaert, P., Valero, A., Geeraerd, A.H., Vermeulen, A., Jacxsens, L., Goh, K.K., De Loy, A., Van Impe, J.F. \& Devlieghere, F. (2009): Prevalence and challenge tests of Listeria monocytogenes in Belgian produced and retailed mayonnaise-based deli-salads, cooked meat products and smoked fish between 2005 and 2007. Int. J. Food Microbiol., 133(1-2), 94-104. 